\title{
Den tabte pointe i Georg Brandes afhandling om det uendeligt små og det uendeligt store i poesien
}

\author{
Af cand.mag. H. P. Rohde
}

Sikkert den berømteste og nok den mærkeligste af Georg Brandes' kritiske småafhandlinger er den, han skrev om Shakespeares Henrikden Fjerde-med den påfaldende langstrakte titel: "Det uendeligt Smaa" og "det uendeligt Store" $i$ Poesien.

Den stod oprindelig i det nu forlængst hedengangne Illustreret Tidende, den 26. september 1869, som supplement til en tidligere anmeldelse af den norske digter A. Munchs tragiske drama Lord William Russell.

Brandes havdeikkelevnet dettenu ganske glemte, oehlenschlägerske efterklangs-skuespil megen ære. I den følgende artikel tog han så - med hans eget udtryk - „Shakespeare ned af hylden " og forklarede, hvor „langt, uendelig langt" vi stadig var bag efter den store englænder i skildring af virkeligheden.

Det, han fremhæver hos Shakespeare, er sansen for "det uendeligt smaa, som udgør Livet" og evnen til derfra at nå "det uendeligt store", der sammenfatter og anskueliggør "en hel Tid og en hel Nation". Ved en række af eksempler viser han, hvordan Shakespeare forstår at tage virkeligheden på kornet. Særligt slående i scenen mellem Henrik Hotspur og hans nysgerrige, utålmodige hustru, hvor hun udbryder:

„Nu brækker jeg din lillefinger, Henrik,

Hvis ei Du siger mig den rene sandhed."

Georg Brandes bemærker: „Dette træk er rent ud guddommeligt." Det er på én gang så uendelig lidt og dog samtidig så uendelig meget - nemlig et billede på selve „det Kvindelige som vor hele dramatiske Litteratur forgjæves har gjort Jagt paa." 
Der er et og andet, der er mærkeligt ved denneartikel. Først og fremmest dens udpræget teoretiske og abstrakte karakter. Både i stil og struktur. Helt igennem er den bygget op over overskriftens tese - som jo samtidig er en antitese - og søger at demonstrere tesens gyldighed indenfor digtningens verden, næsten som om det gjaldt en matematisk eller geometrisk bevisførelse. Sådan skrev Georg Brandes i sine ganske unge dage, da han var fyldt til randen med Hegel og Heiberg og hele den periodes vindtørre æstetik. Men i 1869 var alt det et tilbagelagt stadium. Nu var han godt i gang med at tilegne sig den friske, smidige, levende, nutidige, mundrette sproglige stil, hvormed han i de kommende år skulle lægge det læsende publikum for sine fødder. Så charmerende var der ikke før skrevet på dansk om teater og litteratur.

\section{Hvorfor nu dette tilbagefald?}

Men ikke mindre mærkelig er selve overskriften. Uvilkårlig spørger man: hvor stammer det egentlig fra? Det lyder som et citat eller et bevinget ord. Og faktisk er det også som sådant indgået i den almindelige bevidsthed. Slår man op i Vogel-Jørgensens Bevingede Ord (5. udg. 1963), får man klar besked:

“Det uendeligt Smaa og det uendeligt Store i Poesien - berømt sætning af Georg Brandes. Den fremkom 1870 i hans anmeldelse af A. Munch's Lord William Russell og Shakespeare's Henrik den Fjerde."

Ja, det er jo ikke til at tage fejl af - men er det rigtigt? Meget - og tildels en ubestemt fornemmelse - tyder på, at Georg Brandes har sin usædvanlige antitese andetsteds fra. Forskningen har da også været inde på det. Og forskningen, det vil især sige Paul V. Rubow. Rubow er jo den, der har grundlagt Georg Brandes-studiet, og det er også ham, der mest har bidraget til at gøre artiklen berømt. Ofte har han fremhævet den. I Dansk biografisk Leksikon skriver han helt poetisk, at Brandes' nye litteraturopfattelse „satte sin mest tillokkende Blomst i hans Anmeldelse af A. Munchs ,"Lord William Russell" og Shakespeares "Henrik IV“. Og ofte har han kredset om problemet, hvorfra Brandes har det gådefulde ord.

Det er også lykkedes ham at nå et godt stykke vej. Skarpsindigt har han påvist, hvordan den franske kritiker Taine, Georg Brandes' læremester, om hvem Brandes netop på samme tid havde skrevet disputats, i sin 
bog La Fontaine et ses fables har brugt „Ord som genfindes hos Georg Brandes". Han kan tilmed citere en længere udredning i denne bog, som ganske svarer til Shakespeare-artiklen, og hvor både udtrykkene „l'infiniment petit" og "l'infiniment grand" forekommer. Afsluttende skriver Rubow: "Udtrykket det uendeligt smaa findes ogsaa andetsteds hos Taine. Begreberne kan føres tilbage til Pascals "deux infinis" (de grandeur \& de petitesse) ja forekommer allerede i platonisk og nyplatonisk Filosofi." (Rubow: Dansk litterær Kritik, 1921, side 257.)

Altsammen udmærket - men stadig stod overskriften i al sin antitetiske og programmatiske prægnans uanfægtet, som om den fuldt færdig var udsprunget af Georg Brandes' eget hoved. Og stadig var der noget uforklaret ved hans pludselige genoptræden som Hegelsk-Heibergsk teoretiserende skematiker.

En eller anden form for forklaring på baggrunden for eller stødet til den overraskende artikel manglede stadig.

I en lille årrække har jeg haft problemet i tankerne - eller rettere - jeg er flere gange blevet mindet om det under læsning med ganske andre formål. Det har her vist sig, at den franske læseverden må have haft ganske godt kendskab til det omtalte udtryk, længe før Taine benyttede det. F.eks. kan det påvises hos den romantiske forfatter og særlig som bibliofil bekendte Charles Nodier, der i sin sidste bog, fra 1844, Franciscus Columna, roser en forfatter for ",esprit", fantasi og andre gode ting, "når han blot ikke forfalder til biografiens og bibliografiens endeløse småtterier - „Les infiniment petits de..."

Mere interessant er det nok, at Frankrigs store folkelige visedigter Béranger, Napoleon-mytens skaber og opretholder op gennem det 19. århundrede, ligefrem kalder en af sine viser: Les infiniment Petits - altså: „De uendeligt Små". Visen er skrevet før 1837 og tyder altså på, at udtrykket ved den tid har været almindelig kendt i den brede læsekreds, Béranger henvendte sig til.

Men ikke var det lykkedes nogetsteds at påvise hele antitesens forekomst, før den stod som overskrift i Illustreret Tidende i 1869.

Problemer af denne art er vanskelige at løse. Egentlig systematisk søgen lader sig ikke gennemføre. Litteraturens verden er for stor. Hvad der udkræves er ganske simpelt tålmodighed og held. Sådan som det gik mig.

En dag for et par år siden stod jeg foran en af de store bogkasser, der garnerer den herlige boggade, Fiolstræde, i næsten hele dens længde. Blikket vandrede velgørende ufortravlet henover de utallige kendte og ukendte 
bogtitler. For det er jo det mærkelige - hvor gammel man end bliver - stadig møder man aldeles ukendte bogtitler, også blandt de ældre bøger. Og nye titler er som ny verdener, man kommer til at drømme ...

Så var det jeg fikøje på en hyggelig gammel bog, ret stor og tyk, med rig gammeldags snirklet forgyldning på ryggen, som man brugte det i midten af forrige århundrede. Titlen var forjættende: Naturens Vidundere. Jeg åbnede bogen - slog op på titelbladet - og var nær gået bagover! Der stod lige for mine øjne - hvad jeg havde søgt så længe!

For at give læseren så meget som muligt af selvoplevelsens glæde, skal jeg referere titelbladet linje for linje:

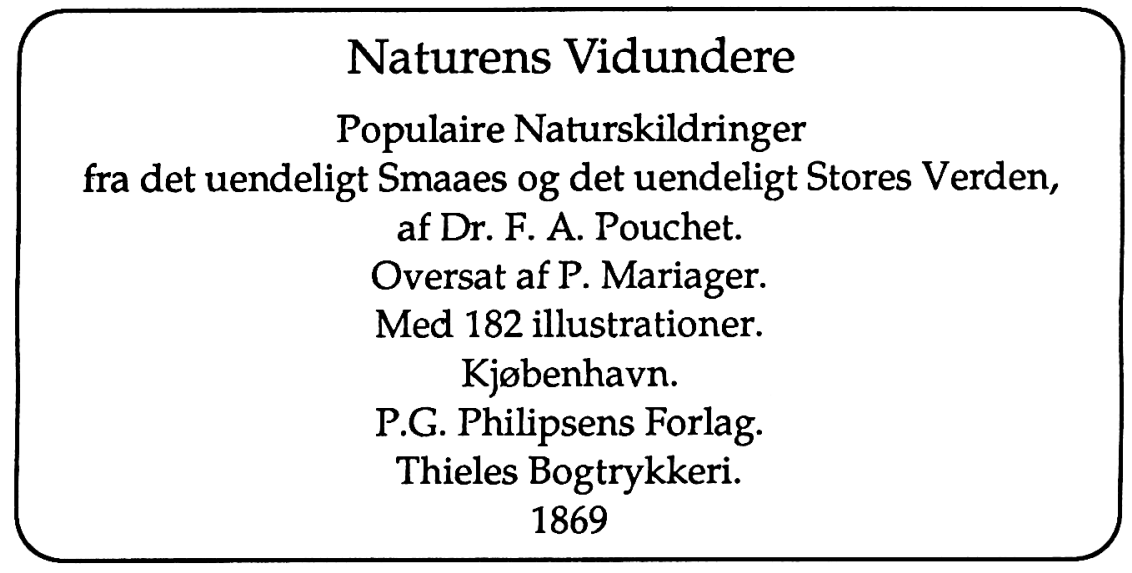

Denne prægtige bog, for sin tid overdådigt udstyret med billeder, har været en af de store og mest omtalte udgivelser i året forud for Georg Brandes' artikel. Den udkom i hefter, eller leveringer, som det dengang hed, den første levering allerede $i$ juni 1868, den sidste i juni 1869. Man kan sige sig selv, at den lange udgivelsestid har bidraget sit til at indprente den ejendommelige undertitel i publikums bevidsthed. Enhver læsende Kobenhavner har kunnet sætningen udenad.

Der kan næppe være tvivl om, at vi her har forklaringen på den gådefulde titel. Som den fødte journalist Brandes også var, har han set, at han her fik et glimrende blikfang forærende. Det har moret ham - som det har moret hans publikum - at han kunne gribe det populære slogan i flugten og indsætte det i en af sine anmeldelser: Her kan I se - det er ikke blot i naturens verden, men også i poesiens, at loven om det uendeligt små og det uendeligt store kan påvises!

Men naturhistoriske værker forældes hurtigt. Den i sin tid så kendte 
det uendeligt Smaae...

Mikroskopiske Smaadyr (100 Gange forstørrede) fra Firnsneen paa Monte Rosa i over 11,000 Fods Høide over Havet.
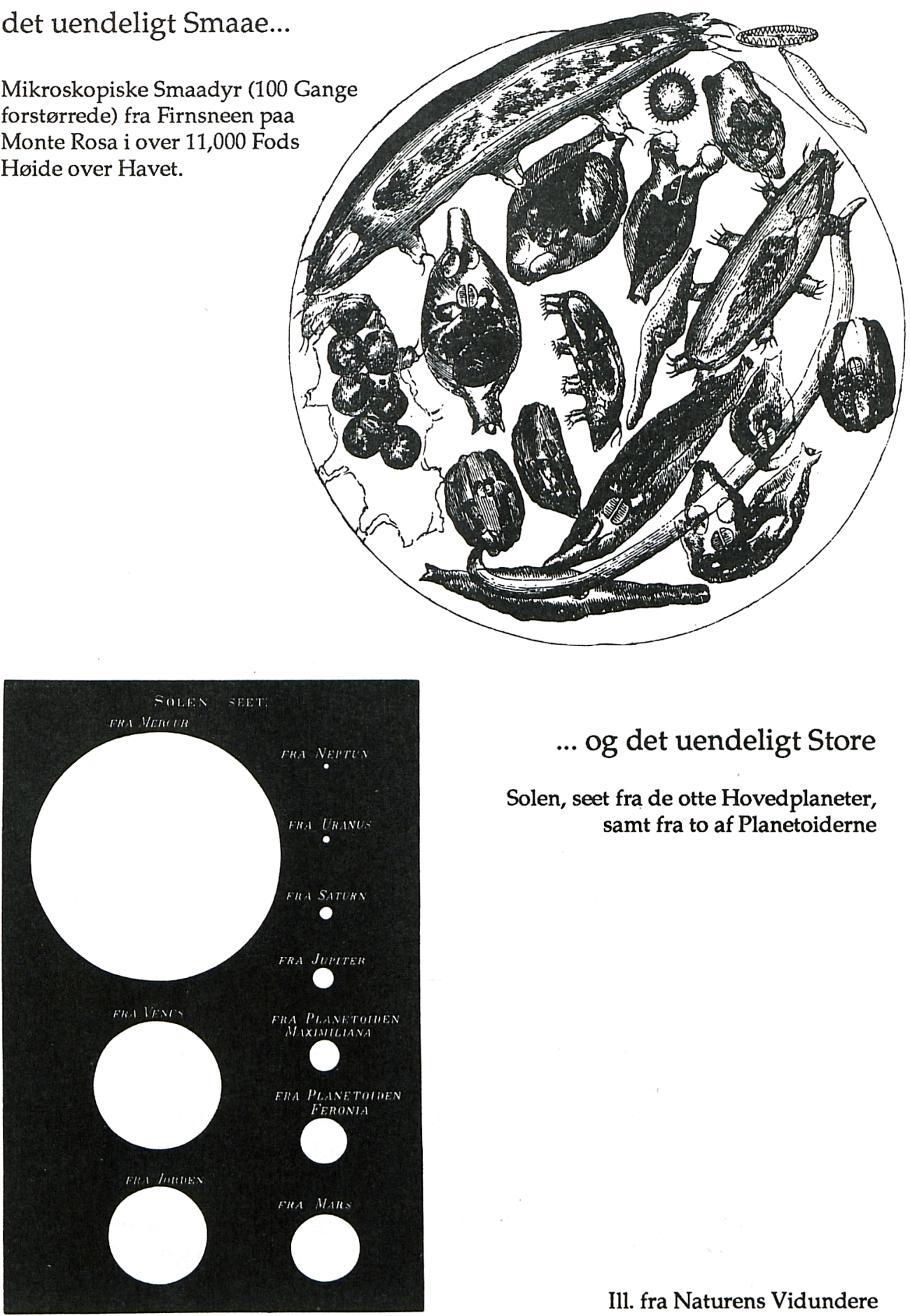

\section{... og det uendeligt Store}

Solen, seet fra de otte Hovedplaneter, samt fra to af Planetoiderne

Ill. fra Naturens Vidundere 
bog med den tankevækkende titel er for længst glemt - og med den den oprindelige pointe.

Der er imidlertid noget at tilføje. Forfatteren af antitesen var nemlig ikke, som man kunne tro, Pouchet. Så at Brandes' sætning altså på en måde er et citat af et citat. Den virkelige ophavsmand nævnes i selve tekstens første linjer: her læser man:

" 'Vor indbildningskraft overvældes ligesaa vel af det uendeligt Smaa som af det uendeligt Store', siger Bonnet, en af de utrætteligste populaire Forfattere, som Naturhistorien har at opvise."

Men hvem var da egentlig Bonnet, har man lov at spørge. Det navn er vist i dag ikke almindeligt bekendt. Og dog har vi danske ganske særlig grund til at mindes denne mand.

Charles Bonnet (1720-1793) var fransk-schweizer og havde sin bopæl i den lille by Genthod ved Genfersøen, knap en mils vej nord for Genève. Den citerede sætning er typisk for ham. Atter og atter støder man i hans skrifter på nye udtryk for denne modsætning, som gennemsyrer hans tankeverden. Betegnende er en udtalelse i hans Essai de Psychologie: „Al storhed og skønhed i solkuglen står tilbage for - jeg vil ikke sige en menneskehjerne, jeg vil sige en fluehjerne."

Han begyndte som naturforsker, gjorde flittigt brug af mikroskopet og nåede at gøre epokegørende opdagelser vedrørende insekternes liv. Fra ham stammer iøvrigt fagordene insektologi og entomologi. Men hans syn tog skade, og hans senere forfatterskab blev overvejende af filosofisk karakter.

Ikke uden selvfølelse kaldte han sig „Filosoffen i Genthod" - nok også med et lille bistert nik over til naboen en halv mils vej ind i landet, Voltaire - „Filosoffen i Ferney“. De to var modpoler. Bonnet lige så alvorlig og from, som Voltaire skeptisk og sarkastisk.

Det var Bonnets forfatterskab, der bragte ham i forbindelse med Danmark. I 1760 udgav han her i landet sit skrift om sjælens egenskaber dog på fransk. Det blev trykt i København af de to schweiziske bogtrykkerbrødre Philibert - en statelig kvart med en trykt dedikation på flere sider til den danske konge, Frederik V.

Bonnet lagde megen vægt på sine bøgers udstyr og indbød flere danske kunstnere til at bo hos sig i den anledning. Sådan gik det til, at Jens Juel kom til at male Bonnets portræt, som Clemens omsatte til det ypperlige 


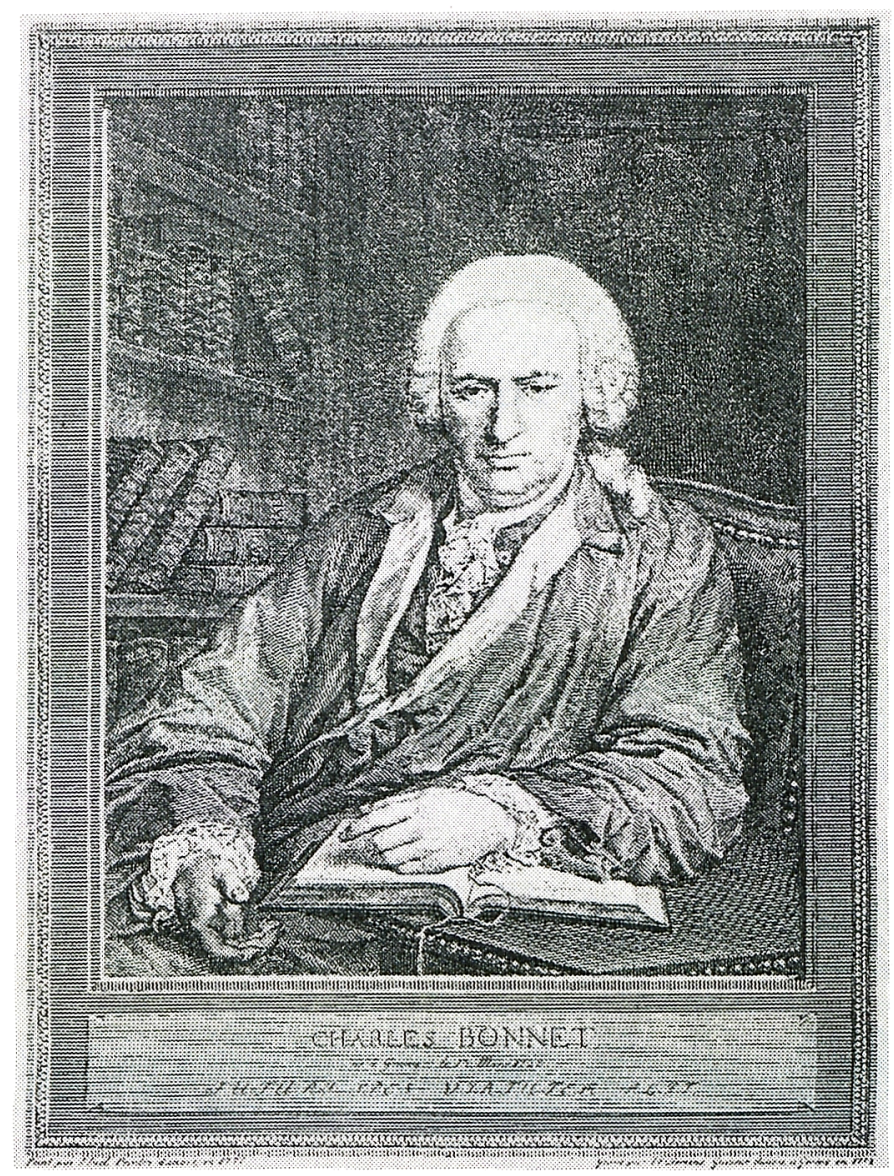

Filosoffen Charles Bonnet ved sin daglige meditation over biblen. - Jens Juels europæisk berømte portræt fra 1777, gengivet i kobberstik 1778 af Clemens og udsendt med Bonnets værker i 1779.

kobberstik, der pryder første bind af Bonnets Oeuvres fra 1779. Det blev et hovedværk i dansk kunst, højt beundret ude i Europa. Bonnet selv skrev i fortalen, at Jens Juel var en ny van Dyck!

Nå - den beskedne danske maler har nu nok bøjet sig for Van Dyck

Men tilbage til Brandes.

Der er dem, der ynder at omtale ham som den store benytter. Også i dette tilfælde har han benyttet. Men så vittigt og åndfuldt, at man fristes til at give Vogel-Jørgensen ret og kalde sætningen for Georg Brandes'. Udskiftningen af naturens verden med poesiens gør jo den afgørende forskel. 